\title{
Protocol
}

\section{Magnetic Trap Construction}

Timothée Lionnet, Jean-François Allemand, Andrey Revyakin, Terence R. Strick, Omar A. Saleh, David Bensimon, and Vincent Croquette

In recent years, techniques have been developed to study and manipulate single molecules of DNA and other biopolymers. In one such technique, the magnetic trap, a single DNA molecule is bound at one end to a glass surface and at the other to a magnetic microbead. Small magnets, whose position and rotation can be controlled, pull on and rotate the microbead. This provides a simple method to stretch and twist the molecule. The system allows one to apply and measure forces ranging from $10^{-3}$ to $>100$ picoNewtons $(\mathrm{pN})$. In contrast to other techniques, the force measurement is absolute and does not require calibration of the sensor. This protocol describes a procedure for building and using a magnetic trap. It gives a method for constructing a microchamber suitable for magnetic tweezers studies, including antibody coating and passivation. It also describes a series of simple steps to achieve end-labeling of DNA anchoring fragments. One anchoring fragment is biotin-labeled and the other is labeled with digoxigenin. The anchoring fragments are then digested and ligated to a central DNA region containing the sequence of interest. The biotinylated DNA is adsorbed onto streptavidin-coated magnetic beads, and the DNA-bead mixture attaches specifically to the antidigoxigenin-coated surface of the microchamber.

MATERIALS

Reagents

It is essential that you consult the appropriate Material Safety Data Sheets and your institution's Environmental Health and Safety Office for proper handling of equipment and hazardous materials used in this protocol.

RECIPE: Please see the end of this article for recipes indicated by $<R>$. Additional recipes can be found online at http://cshprotocols.cshlp.org/site/recipes.

Antidigoxigenin, polyclonal (100 $\mu \mathrm{g} / \mathrm{mL}$ in phosphate-buffered saline; Roche)

Biotin-16-dUTP (1 mM; Roche)

Digoxigenin-11-dUTP (1 mM)

dNTPs $(10 \mathrm{~mm})$

Ligase buffer $(10 \times)$

$\mathrm{Mg}^{2+}(25 \mathrm{~mm})$

$\mathrm{NaOH}(5 \mathrm{M})$

NEBuffer 4 (New England Biolabs)

Passivation buffer $<\mathrm{R}>$

Different protein systems may need different passivation buffers. The optimal passivation buffer for a particular application is best determined experimentally.

Adapted from Single-Molecule Techniques (ed. Selvin and Ha). CSHL Press, Cold Spring Harbor, NY, USA, 2008.

(c) 2012 Cold Spring Harbor Laboratory Press

Cite this article as Cold Spring Harbor Protoc; 2012; doi:10.1101/pdb.prot067496 
T. Lionnet et al.

pBluescriptKS $(250 \mathrm{ng} / \mu \mathrm{L})$

Phosphate-buffered saline (PBS)

Primer A (CTAAATTGTAAGCGTTAATATTTTGTTAAA) (100 $\mu \mathrm{m})$

Primer B (TATCTTTATAGTCCTGTCGGGTTTCGCCAC) $(100 \mu \mathrm{m})$

pSB $110(100 \mathrm{ng} / \mu \mathrm{L})$

This plasmid has restriction enzyme sites for Xhol, Aatll, and Eco109l (gift of S. Bigot).

Restriction enzymes: XhoI, AatII, Eco109I

Sigmacote (Sigma-Aldrich)

T4 DNA ligase (Fermentas)

Taq (New England Biolabs)

Taq buffer without $\mathrm{Mg}^{2+}(10 \times)$

Water, double-distilled $\left(\mathrm{ddH}_{2} \mathrm{O}\right)$

Equipment

Beads, magnetic, streptavidin-coated, 1- $\mu$ m diameter (Dynabeads; MyOne; Invitrogen)

Beads, polystyrene, nonmagnetic, 2- $\mu$ m diameter (Polysciences) (optional; see Step 33)

These beads are used as reporters of the microscope mechanical drift motion; see Single-Molecule Studies

Using Magnetic Traps (Lionnet et al. 2012).

Connectors, polypropylene (Fisher Bioblock or similar)

Coverslips, glass $(24 \times 60 \mathrm{~mm}$; Menzel-Glaser $)$

Hot plate

Magnets (NdFeB cubic, $5 \times 5 \times 6 \mathrm{~mm}$; VacuumSchmelze)

Microcentrifuge tubes

Microcon (YM-100 column; Millipore)

Microscope, inverted

Mylar film (50 $\mu$ m thick)

PCR thermal cycler

Petri dish

Rotator

Syringe

Tape, double-sided (Duplocoll 375; Lohmann-Durabloc)

Tape, double-sided (60 $\mu \mathrm{m}$ thick; Duplocoll 3205; Lohmann-Durabloc)

Translation stage motor (PI C-150.PD; Polytec)

Translation stage, motorized (PI M-126.PD; Polytec)

Tygon tubing

\section{METHODS}

Digestion of the Central DNA Fragment

1. Combine the following ingredients:

$10 \mu \mathrm{L}$ pSB110

$1 \mu \mathrm{L}$ XhoI

$1 \mu \mathrm{L}$ AatII 
Labeling of DNA Anchoring Fragments

Perform labeling with digoxigenin and biotin separately, in parallel.

4. Combine the following ingredients:

$1 \mu \mathrm{L}$ pBluescriptKS

$1 \mu \mathrm{L}$ Primer A

$1 \mu \mathrm{L}$ Primer B

$1.5 \mu \mathrm{L}$ dNTPs

$2 \mu \mathrm{L} \mathrm{Mg}^{2+}$

$5 \mu \mathrm{L}$ Taq buffer w/o $\mathrm{Mg}^{2+}$

$1 \mu \mathrm{L} \mathrm{Taq}$

$1.5 \mu \mathrm{L}$ labeled dUTP (digoxigenin or biotin)

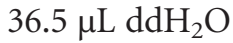

5. Perform PCR as follows:

i. An initial denaturation step for $5 \mathrm{~min}$ at $94^{\circ} \mathrm{C}$.

ii. Thirty cycles for $30 \mathrm{sec}$ at $94^{\circ} \mathrm{C}$, for $1 \mathrm{~min}$ at $54^{\circ} \mathrm{C}$, and for $1 \mathrm{~min}$ at $72^{\circ} \mathrm{C}$.

iii. A final incubation for $5 \mathrm{~min}$ at $72^{\circ} \mathrm{C}$.

6. Purify the PCR products with a Microcon YM-100 column according to the manufacturer's protocol.

Digestion of Dig-Labeled Fragments

7. Combine the following ingredients:

$10 \mu \mathrm{L}$ Dig-labeled fragment ( $1 \mathrm{~kb}$ at $50 \mathrm{ng} / \mu \mathrm{L}$ ) (from Step 6)

$2 \mu \mathrm{L}$ XhoI

$4 \mu \mathrm{L}$ NEBuffer 4

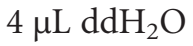

8. Incubate for $1 \mathrm{~h}$ at $37^{\circ} \mathrm{C}$.

9. Incubate for $20 \mathrm{~min}$ at $65^{\circ} \mathrm{C}$.

\section{Digestion of Biotin-Labeled Fragments}

10. Combine the following ingredients:

$10 \mu \mathrm{L}$ biotin-labeled fragment ( $\sim 1 \mathrm{~kb}$ at $50 \mathrm{ng} / \mu \mathrm{L}$ ) (from Step 6)

$2 \mu \mathrm{L}$ AatII

$4 \mu \mathrm{L}$ NEBuffer 4

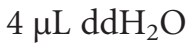

11. Incubate for $1 \mathrm{~h}$ at $37^{\circ} \mathrm{C}$.

12. Incubate for $20 \mathrm{~min}$ at $65^{\circ} \mathrm{C}$.

Ligation of Anchoring Fragments to Central DNA Fragment

13. Combine the following ingredients:

$2 \mu \mathrm{L}$ digested central fragment $(\sim 30 \mathrm{ng} / \mu \mathrm{L})$ (from Step 3 )

$15 \mu \mathrm{L}$ digested dig fragment $(\sim 20 \mathrm{ng} / \mu \mathrm{L}$ ) (from Step 9 ) 
T. Lionnet et al.

$15 \mu \mathrm{L}$ digested biotin fragment ( $\sim 20 \mathrm{ng} / \mu \mathrm{L}$ ) (from Step 12)

$10 \mu \mathrm{L} 10 \times$ ligase buffer

$4 \mu \mathrm{L}$ T4 DNA ligase

$52 \mu \mathrm{L} \mathrm{ddH}_{2} \mathrm{O}$

14. Incubate for $2 \mathrm{~h}$ at $16^{\circ} \mathrm{C}$.

15. Incubate for $20 \mathrm{~min}$ at $65^{\circ} \mathrm{C}$.

\section{Treatment of Glass Coverslips}

16. Rinse coverslips with $5 \mathrm{~m} \mathrm{NaOH}$. Let sit for $\sim 1 \mathrm{~min}$.

17. Rinse with $\mathrm{ddH}_{2} \mathrm{O}$.

18. Incubate on hot plate for $5 \mathrm{~min}$ at $125^{\circ} \mathrm{C}$.

19. Add Sigmacote and incubate for 1-2 $\mathrm{min}$.

20. Blow dry.

21. Incubate on hot plate for $30 \mathrm{~min}$ at $125^{\circ} \mathrm{C}$.

22. Rinse with $\mathrm{ddH}_{2} \mathrm{O}$.

\section{Construction of Microchamber}

The dimensions of the resulting channel are $50 \mathrm{~mm} \times 5 \mathrm{~mm} \times 60 \mu \mathrm{m}$, giving a volume of $15 \mu \mathrm{L}$. See Figure $1 B$ and Single-Molecule Studies Using Magnetic Traps (Lionnet et al. 2012) for details.

23. Cut channel $(50 \times 5 \mathrm{~mm})$ in $60-\mu \mathrm{m}$-thick double-sided tape.

24. Drill two holes in the $50-\mu \mathrm{m}$-thick Mylar sheet.
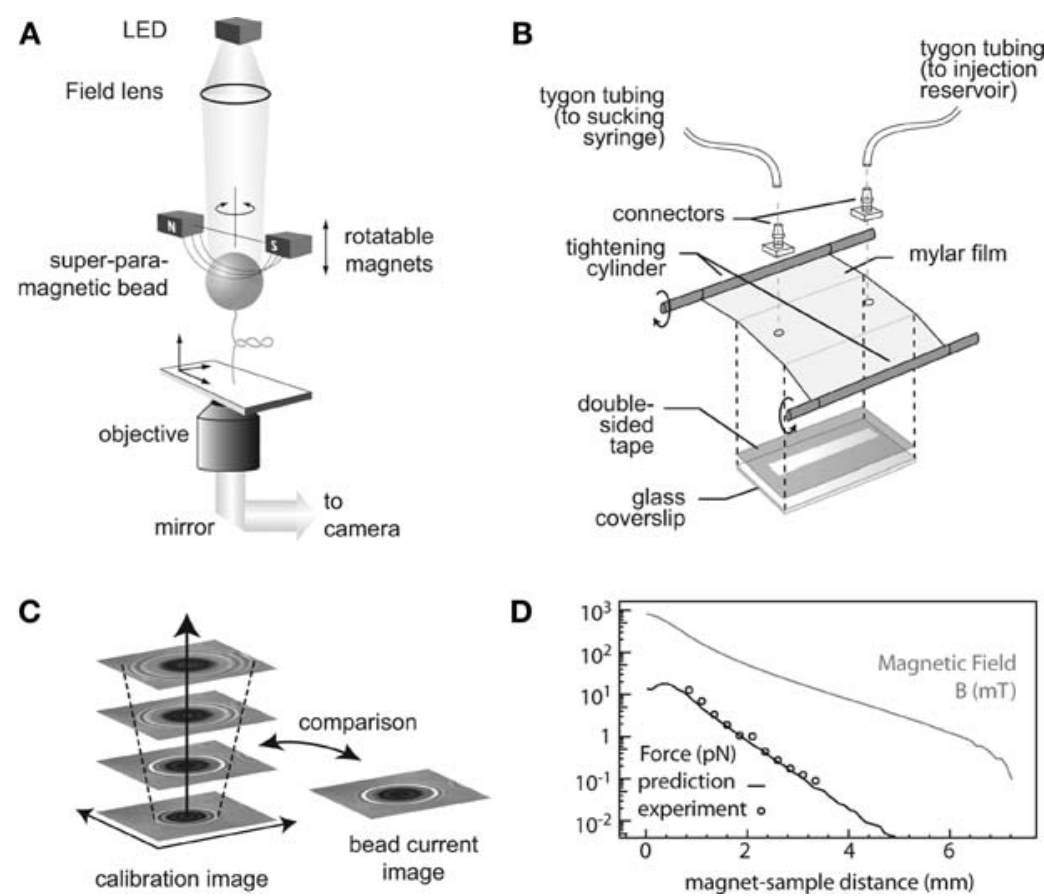

FIGURE 1. Experimental setup. (A) Schematic view of the setup (not to scale). (B) Design of the experimental microchamber. $(C)$ Principle of the bead $z$ position measurement. At each time, the current bead image is compared with the calibration image (see text). (D) Experimental measurement of the magnetic field (gray line) created by the magnet setup described in the text. Prediction of the resulting force generated on 1- $\mu \mathrm{m}$-diameter beads (MyOne, Dynabeads) using manufacturer's magnetization data (black circles). Force actually measured using the method described in the text on a similar bead (black line). 


\section{Antibody Treatment and Passivation of Microchamber}

31. Add $50 \mu \mathrm{L}$ of antidig to the microchamber.

32. Incubate in a humidified chamber (e.g., Petri dish with wet tissue) overnight at $37^{\circ} \mathrm{C}$.

33. To bind nonmagnetic beads to the surface, proceed to Step 34. Otherwise, proceed to Step 40.

\section{Fixation of Nonmagnetic Beads}

Depending on the antibody/passivation combination used, a different protocol for binding nonmagnetic beads to the surface might be needed. In some cases, nonspecific binding of magnetic beads to the surface might be sufficient to provide the desired amount of fixed beads.

34. Rinse chamber with $\mathrm{ddH}_{2} \mathrm{O}$.

35. Inject $10 \mu \mathrm{L}$ of undiluted polystyrene bead solution into the reservoir connected to the chamber.

36. Use the syringe to draw the bead solution into the microchamber. Keep the reservoir full by adding the desired buffer.

37. When the beads are distributed evenly along the length of the chamber, stop the flow.

38. Allow the polystyrene beads to sediment. Incubate for $\sim 1 \mathrm{~min}$. (The exact incubation time may vary from one chamber to another.)

39. When the desired amount of beads is bound to the surface, aspirate excess buffer with the syringe.

40. Rinse with passivation buffer. (This also rinses away unbound nonmagnetic beads.)

41. Incubate with passivation buffer in humidified chamber for $2-4 \mathrm{~h}$.

Microchambers can be stored at $4^{\circ} \mathrm{C}$ until use.

\section{Anchoring of DNA to Magnetic Beads}

42. Wash $10 \mu \mathrm{L}$ of magnetic beads $(10 \mathrm{mg} / \mathrm{mL})$ in $200 \mu \mathrm{L}$ of passivation buffer.

43. Resuspend beads in $10 \mu \mathrm{L}$ of passivation buffer.

44. Deposit a 1- $\mu \mathrm{L}$ drop of DNA construct at the bottom of a microcentrifuge tube.

45. Deposit the $10 \mu \mathrm{L}$ of beads onto the drop of DNA. Flick tube to mix.

46. Place on rotator for $5 \mathrm{~min}$ to keep beads from sedimenting.

47. Dilute the reaction by gently depositing $40 \mu \mathrm{L}$ of passivation buffer onto the DNA-bead solution.

48. Resuspend the beads to homogeneity by tipping the tube upside-down (without causing the liquid to drop) or spinning the tube between thumb and forefinger.

Bead-DNA complexes can be stored a few days before use. Store on a rotator to keep beads from sedimenting. 
T. Lionnet et al.

Anchoring the DNA-Bead Mixture in the Microchamber

49. Place the magnets as far from the flow cell as possible $(\sim 25 \mathrm{~mm})$.

50. Inject $5 \mu \mathrm{L}$ of the bead-DNA mixture (from Step 48) into the reservoir connected to the chamber.

51. Use the syringe to draw the bead-DNA solution into the microchamber. Keep the reservoir full by adding the desired buffer.

52. When the beads are distributed evenly along the length of the chamber, stop the flow.

53. Allow magnetic beads to sediment. Incubate for $5 \mathrm{~min}$.

54. Rinse with desired buffer.

At this point, the samples are ready for observation and experimental manipulation with the inverted microscope/magnetic tweezers assembly.

See Troubleshooting.

\section{TROUBLESHOOTING}

Problem (Step 54): DNA-magnetic bead complexes interact nonspecifically with the surface of the microchamber.

Solution: Add small amounts (e.g., $\sim 0.1 \% \mathrm{w} / \mathrm{v}$ ) of bovine serum albumin (BSA) and Pluronic F127 in the desired buffer when anchoring the DNA-coated beads to the microchamber. For background information on magnetic traps, see Single-Molecule Studies Using Magnetic Traps (Lionnet et al. 2012).

\section{RELATED INFORMATION}

The magnetic trap setup described for this protocol (microscope, magnets, translation stage, etc.) is similar to a commercially available version (PicoTwist; see www.picotwist.com). For another example of a specific protocol, see Revyakin et al. (2003).

Passivation Buffer

$10 \mathrm{mg} / \mathrm{mL}$ bovine serum albumin (BSA; Promega)

$1 \mathrm{~mm}$ EDTA

$10 \mathrm{~mm}$ phosphate buffer ( $\mathrm{pH} 8.0$ )

$10 \mathrm{mg} / \mathrm{mL}$ Pluronic F127 surfactant (Sigma-Aldrich)

$10 \mathrm{~mm}$ sodium azide

\section{ACKNOWLEDGMENTS}

We acknowledge helpful discussions with K.C. Neumann, G. Lia, G. Charvin, E. Praly, and A. Meglio. We thank G. Charvin for help with figure design, and S. Bigot and F.-X. Barre for help in DNA substrate preparation. This work was supported by the Centre National de la Recherche Scientifique, the Dynamique et Réactivité des Assemblages Biologiques, the Ecole Normale Superieure, and Universities Paris VII and VI and by grants from Association pour la Recherche contre le Cancer, Agence Nationale de la Recherche, and the European Union (Biosense).

\section{REFERENCES}

Lionnet T, Allemand J-F, Revyakin A, Strick TR, Saleh OA, Bensimon D, Croquette V. 2012. Single-molecule studies using magnetic traps. Cold Spring Harb Protoc doi: 10.1101/pdb.top067488.
Revyakin A, Allemand JF, Croquette V, Ebright RH, Strick TR. 2003. Singlemolecule DNA nanomanipulation: Detection of promoter-unwinding events by RNA polymerase. Methods Enzymol 370: 577-598. 


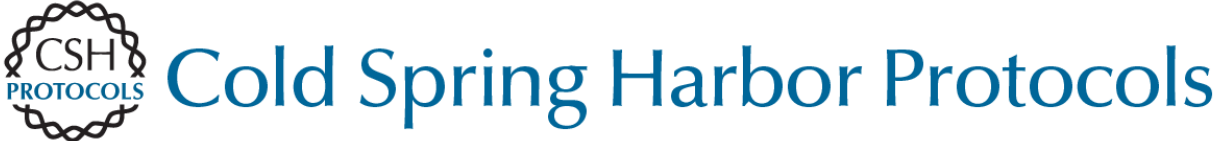

\section{Magnetic Trap Construction}

Timothée Lionnet, Jean-François Allemand, Andrey Revyakin, Terence R. Strick, Omar A. Saleh, David Bensimon and Vincent Croquette

Cold Spring Harb Protoc; doi: 10.1101/pdb.prot067496

\begin{tabular}{rc}
$\begin{array}{r}\text { Email Alerting } \\
\text { Service }\end{array}$ & Receive free email alerts when new articles cite this article - click here. \\
\hline $\begin{array}{c}\text { Subject } \\
\text { Categories }\end{array}$ & $\begin{array}{c}\text { Browse articles on similar topics from Cold Spring Harbor Protocols. } \\
\text { Amplification of DNA by PCR (85 articles) } \\
\text { DNA:Protein Interactions (74 articles) } \\
\text { Imaging/Microscopy, general (579 articles) } \\
\text { Labeling for Imaging (339 articles) }\end{array}$ \\
\hline
\end{tabular}

